\title{
Vena cava filter placement in a duplicated infrarenal inferior cava venous system with azygous continuation
}

\author{
Gustavo Lagrotta, ${ }^{1,2}$ Mauricio Danckers, ${ }^{3}$ Roberto Fourzali ${ }^{1}$
}

\begin{abstract}
${ }^{1}$ Pulmonary Disease Fellow, Aventura Hospital and Medical Center, Aventura, Florida, USA ${ }^{2}$ Graduate Medical Education, Nova Southeastern University, Fort Lauderdale, Florida, USA ${ }^{3}$ Intensive Care Unit, Aventura Hospital and Medical Center, Aventura, Florida, USA
\end{abstract}

\section{Correspondence to}

Dr Gustavo Lagrotta; gustavo.lagrottasaavedra@ hcahealthcare.com

Accepted 30 June 2021

\section{DESCRIPTION}

A 50-year-old man with atrial fibrillation without anticoagulation presented to the hospital after tonic-clonic seizures, followed by pulseless cardiopulmonary arrest with return of spontaneous circulation after $2 \mathrm{~min}$. Imaging demonstrated a left superior cerebellar thromboembolic ischaemic stroke associated with trace subarachnoid haemorrhage. Further studies revealed bilateral basilic and left cephalic superficial vein thrombosis, and right brachial and right popliteal deep vein thrombosis. Non-contrast chest and abdomen CT revealed a duplicated infrarenal inferior vena cava (IVC) with azygous continuation and absence of suprarenal IVC (figure 1A,B). Due to the inability to start systemic anticoagulation and anatomical variance, a retrievable vena cava filter (Cordis OPTEASE) was placed in the right infrarenal IVC via femoral access site under fluoroscopy (video 1).

Several IVC congenital anomalies and their associations with findings such as thromboembolic events have been documented. ${ }^{12}$ The development of the IVC begins between the sixth and eight gestational weeks and involves anastomoses between the paired embryonic cardinal veins. These form the hepatic, suprarenal, renal and infrarenal segments. ${ }^{3}$ It is theorised that duplication of the IVC results from persistence of the supracardinal veins, with a prevalence of $0.2 \%-3.0 \%$ in the general population. ${ }^{4} \mathrm{~A}$ classification of duplicated IVC has been proposed: type I (major duplication, where both IVCs have symmetrical trunks and similar size as the preaortic trunk) as seen in our patient, type II (minor type, where both IVCs have symmetrical trunks but are smaller than the preaortic trunk) and type III (asymmetrical type, where the left IVC has a smaller trunk than the right IVC, and with variable sizes of the preaortic trunk). ${ }^{5} \mathrm{~A}$ novel type IV (left IVC with a larger trunk than the right IVC) has also been proposed. ${ }^{6}$

In addition, the absence of the suprarenal IVC with azygous continuation is theorised to be failure to form the right subcardinal-hepatic anastomosis, with resulting atrophy of the right subcardinal vein. The prevalence of azygous continuation has been noted to $0.6 \% .{ }^{4}$ However, these two IVC abnormalities presenting simultaneously have yet to be thoroughly documented and pose a particular challenge in our patient.

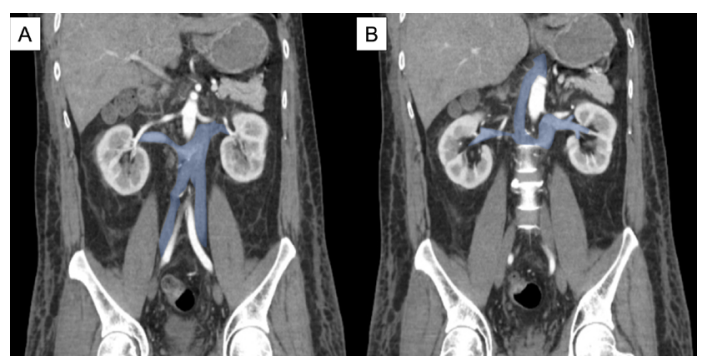

Figure 1 Coronal view of contrast CT of the chest and abdomen. (A) Duplicated infrarenal IVC and (B) azygous continuation and absence of suprarenal IVC courses are shaded in blue. IVC, inferior vena cava.

These anomalies are typically incidental findings and the most current prevalence is likely underestimated.

The patient's anatomical variant prohibited for the eventual filter retrieval through jugular vein access. ${ }^{7}$ In order to circumvent this issue, a a retrievable vena cava filter was inserted in the right infrarenal IVC through the right femoral vein. This filter has a caudally oriented hook designed for a femoral vein retrieval. ${ }^{8}$ It has shown safe insertion, removal and repositioning in patients with normal venous anatomy, and use in anatomical venous variants. ${ }^{9-11}$ Complex variant and thrombus extension are crucial issues affecting the choice of procedure; thus, the optimal position for an IVC filter has yet to be established. Each approach is tailored to the specific anomaly of the case. ${ }^{12}$ We present to the reader the novel deployment of a femoral access

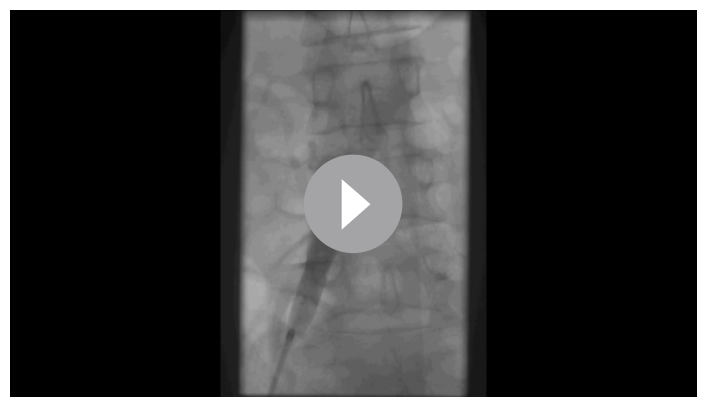

Video 1 IVC filter placement under fluoroscopy. Black arrow pointing to the location of the deployed retrievable vena cava filter. IVC, inferior vena cava. 
site retrievable IVC filter in a patient with a rare venous drainage anatomical variant.

\section{Patient's perspective}

I feel really well, surprisingly well. Everyone I know, all of my family, is in shock of the quick recovery I've made. I have lingering discomfort in my flank, but otherwise I'm feeling good. The findings honestly haven't changed how I go on about my day, I'll still continue to be as healthy as I can in my life.

\section{Learning points}

- Venous anomalies are commonly discovered as an incidental finding and likely occur at higher rates than what has been published.

- Proper anatomical evaluation, equipment selection and procedural planning are key when considering placement of an inferior vena cava filter in a patient with venous drainage system anatomical variants.

Contributors Data collection and drafting of the manuscript: GL. Critical revision and editing of the manuscript: MD. Revision of images: RF.

Funding The authors have not declared a specific grant for this research from any funding agency in the public, commercial or not-for-profit sectors.
Competing interests None declared.

Patient consent for publication Obtained.

Provenance and peer review Not commissioned; externally peer reviewed.

\section{REFERENCES}

1 Petik B. Inferior vena cava anomalies and variations: imaging and rare clinical findings. Insights Imaging 2015;6:631-9.

2 Paddock M, Robson N. The curious case of the disappearing IVC: a case report and review of the aetiology of inferior vena cava agenesis. J Radiol Case Rep 2014:8:38-47.

3 Malaki M, Willis AP, Jones RG. Congenital anomalies of the inferior vena cava. Clin Radiol 2012:67:165-71.

4 Bass JE, Redwine MD, Kramer LA, et al. Spectrum of congenital anomalies of the inferior vena cava: cross-sectional imaging findings. Radiographics 2000;20:639-52.

5 Natsis K, Apostolidis S, Noussios G, et al. Duplication of the inferior vena cava: anatomy, embryology and classification proposal. Anat Sci Int 2010;85:56-60.

6 Klinkhachorn PS, Ritz BK, Umstot SI, et al. Duplication of the inferior vena cava: evidence of a novel type IV. Folia Med Cracov 2020;60:5-13.

7 Kuyumcu G, Walker TG, Gregory Walker T. Inferior vena cava filter retrievals, standard and novel techniques. Cardiovasc Diagn Ther 2016;6:642-50.

8 Montgomery JP, Kaufman JA. A critical review of available Retrievable inferior vena cava filters and future directions. Semin Intervent Radiol 2016;33:079-87.

9 Rosenthal D, Swischuk JL, Cohen SA, et al. OptEase Retrievable inferior vena cava filter: initial multicenter experience. Vascular 2005;13:286-9.

10 Cordis Optease Retrievable inferior vena cava filter. Biomedical Safety Standards 2013;43:141.

11 Hashmi ZA, Smaroff GG. Dual inferior vena cava: two inferior vena cava filters. Ann Thorac Surg 2007;84:661-3.

12 Sartori MT, Zampieri P, Andres A-L, et al. Double vena cava filter insertion in congenital duplicated inferior vena cava: a case report and literature review. Haematologica 2006;91:ECR30.

Copyright 2021 BMJ Publishing Group. All rights reserved. For permission to reuse any of this content visit

https://www.bmj.com/company/products-services/rights-and-licensing/permissions/

BMJ Case Report Fellows may re-use this article for personal use and teaching without any further permission.

Become a Fellow of BMJ Case Reports today and you can:

- Submit as many cases as you like

- Enjoy fast sympathetic peer review and rapid publication of accepted articles

- Access all the published articles

- Re-use any of the published material for personal use and teaching without further permission

\section{Customer Service}

If you have any further queries about your subscription, please contact our customer services team on +44 (0) 2071111105 or via email at support@bmj.com.

Visit casereports.bmj.com for more articles like this and to become a Fellow 